\title{
Implementation of Role-Playing Games in Overcoming Introverted Children
}

\author{
Fathor Rozi 1 , Firdausiah 2 \\ DOI: 10.35445/alishlah.v13i2.629
}

\begin{tabular}{|c|c|}
\hline Article Info & Abstract \\
\hline Keywords: & This study aims to analyze and examine the application of role-playing games in \\
\hline Role-Playing; & overcoming introverted children in early childhood at RA Uswatun Hasanah, \\
\hline Introverted Children & $\begin{array}{l}\text { Maron, Probolinggo. This research uses a qualitative approach, while the type of } \\
\text { research uses case studies. The data analysis technique uses data reduction, data } \\
\text { display, and drawing conclusions or verification. The results showed that the } \\
\text { teacher's steps in implementing role-playing games in overcoming the problems } \\
\text { of introverted children through; Preparation and Planning Analysis, Role- } \\
\text { Playing Engineering, Activity Documentation, Activity Evaluation. This research } \\
\text { has implications for the use of role-playing, especially at RA Uswatun Hasanah. } \\
\text { Introverted children begin to be able to mingle and even adapt to their friends, } \\
\text { albeit slowly. }\end{array}$ \\
\hline
\end{tabular}

Kata kunci:

Bermain Peran;

Anak Introvert

\begin{abstract}
Abstrak
Penelitian ini bertujuan untuk menganalisis dan mengkaji tentang Penerapan Role Playing Game Dalam Mengatasi Anak Introvert pada anak usia dini di RA Uswatun Hasanah, Maron, Probolinggo. Penelitian ini menggunakan pendekatan kulitatif, sedangkan jenis penelitiannya menggunakan studi kasus. Teknik analisis data menggunakan reduksi data, tampilan data, dan penarikan kesimpulan atau verifikasi. Hasil penelitian menunjukkan bahwa Langkahlangkah guru dalam Implementasi Role-Playing Games dalam mengatasi permasalahan anak introvert melalui; Analisis Persiapan dan Perencanaan, Rekayasa Role Playing, Dokumentasi Kegiatan, Evaluasi Kegiatan. Penelitian ini memberikan implikasi dengan penggunaan role playing khususnya di RA Uswatun Hasanah, anak introvert mulai dapat berbaur bahkan beradaptasi dengan teman-temannya meski dengan perlahan.
\end{abstract}

${ }^{1}$ Universitas Nurul Jadid Paiton, Probolinggo, Indonesia

Email: fathorrozi330@gmail.com

2 Universitas Nurul Jadid Paiton, Probolinggo, Indonesia

Email: zahrafirda88@gmail.com 


\section{INTRODUCTION}

Early Childhood Education is one of the human resource development strategies and is a central and basic point. This early age is a golden age but, at the same time, a very critical period in the stage of human development (Yunia, 2016). Early childhood education is a coaching effort aimed at children from birth to the age of six years, which is carried out through educational stimuli to help development, growth both physically and spiritually so that children have further readiness (Lasaiba, 2016).

A good and appropriate learning process affects the quality of learning. To improve the quality of good education, the hope is that students want to understand what is learned and can be applied in real life (Selian, 2019). Therefore, teachers must have innovative knowledge to achieve the learning process optimally (Kristin, 2018). Moreover, early childhood tends to get bored quickly, therefore the right model in implementing learning and stimulating children's development through games (Saihu \& Umar, 2021).

In essence, each individual is different with their characteristics, and this difference is not only from the physical and psychological aspects (Ahour \& Haradasht, 2014). Therefore, the emotions contained in each individual cannot be separated from the aspect of the individual's personality. Introverts tend to be quiet, shy, and uncomfortable in social situations (Ahour \& Haradasht, 2014). Individuals with introverted personality types will be able to open up to the people around them, but this depends on the experience experienced by the individual (Sakinah, 2018).

Social skills and speaking skills are the most natural things done by everyone (Siska, 2011), but not so in introverted personalities. Shy types feel very alert around strangers and get very nervous in unfamiliar surroundings (Jacobs, 2014). Introverts have difficulty developing social relationships and prefer to communicate privately with friends and enjoy every activity done alone or with close friends (Nursyahrurahmah, 2017).

The problems in RA Uswatun Hasanah, Maron, Probolinggo are; some children have introverted (quiet) personalities who cannot mingle and play with their friends. The tendency of introverted children prefer to spend time alone and feel tired after interacting with many people. This results in several aspects of child development not being achieved optimally. The right stimulus is needed so that children get used to socializing with other people.

It can be done with a learning model that interacts socially with the environment in overcoming this problem. One technique that can be used to practice skills in social interaction is role-played (Martin, 2018). Role-play is a technique in learning that can also be applied in guidance services, by acting out parallel situations with real or actual life, used to develop human relations skills. Through role-playing, group members or students learn through the model shown by the players (Hammer et al., 2021). Students also develop understanding and skills in social interaction (Zen et al., 2020). Role-playing is a student learning model which is part of a simulation directed at creating various events of socio-cultural change, actual events or events that may arise (Goh, 2016), while the advantages of the role-play model are exploring the learning material in a variety of ways, obtaining an overview of the newly learned behavior, exploring the feelings of the perpetrator and developing problem-solving skills (Windiastri \& Nurhaeni, 2020). The learning model will make learning more active and increase excitement while respecting individual differences and the diverse intelligence of students (Baharun, 2016).

For this analysis to be more comprehensive, as stated in the background of the problem, the researcher seeks to conduct an initial study of researchers relevant to the subject matter to be studied. The previous research related to role-playing games in dealing with introverted children was carried out by (Filina, 2013) who say Role playing is the sense of playing a role or playing pretend. A role-playing model is a form of safe children's play and forms of play that follows the environment's structure or games using dolls and houses, which dramatize behavior about social problems. With dramatization, children have the opportunity to perform, interpret and play a 
certain role. Through this activity, students will actively discuss their problems and then inform their experiences through speaking activities. Thus, introverted children can interact with their friends who play role-playing. Then (Ayuningtiyas, 2013) said Roleplaying is also known as pretend play, fantasy, fantasy, make-believe, or symbolic. According to Piaget, the beginning of role-playing can be evidence of a child's behavior. He stated that role-playing is characterized by applying stories to objects and repeating pleasant behaviors that are remembered. Piaget stated that children's involvement in role-playing and children's efforts to reach a higher stage than other children is referred to as collective symbolism. He also describes the verbal conversations that children have with themselves as idiosyncratic soliloquies. Next (Kurniawan, 2019) said the techniques that can improve interpersonal communication are role-played techniques and symbolic modeling techniques. Factors that can encourage interest in communicating include personal and situational factors.

The difference of this research from previous research is in the role-playing application. The teacher manipulates the scene before starting the game, where this application adapts to the circumstances and conditions of the child. This research is important to overcome introverted children who are less able to develop their emotional-social intelligence. Then, this research has novelties related to the problems that are the focus of this research to foster self-confidence for introverted children in interacting with people in their environment.

\section{METHODS}

This study uses a qualitative descriptive approach. It is used to find more in-depth information about the application of role-playing games in overcoming introverted children. The type of research used is case studies focused on certain cases to be observed and analyzed carefully. Until completion, This research seeks to describe the symptoms, events, and events happening now. This research photographs the events that will focus on the research and will then be described as they are (Anggraini \& Putri, 2019).

This qualitative research was conducted to describe the findings of the research. Documentation supports completing the data obtained as a support to strengthen the research findings during interviews and observations. The place of research was carried out at the RA Uswatun Hasanah institution in the Probolinggo area, namely Maron sub-district, Probolinggo. Informants who are the subjects of this study are principals, teachers, and students. The samples taken in this study were four students of RA Uswatun Hasanah from groups A and B, from 31 students.

Researchers analyzed the Application of Role-Playing in Overcoming Introverted Children. The data analysis technique uses data reduction, data display, and drawing conclusions or verification. While checking the validity of the data is done through; credibility and confirmability to be completely accurate and credible. In the early stages of data reduction, selecting raw data in the form of notes, then displaying the data by providing an understanding of the data to determine the next step, then concluding the data studied.

\section{FINDINGS AND DISCUSSION}

The results showed that; The application of role-playing games in dealing with introverted children in Ra Uswatun Hasanah, Maron, Probolinggo through the following steps;

\section{Preparation and Planning Analysis}

Before teaching and learning activities are started, a teacher is obliged to prepare complete and systematic learning materials delivered to students. In addition to material, the teacher must also prepare interesting, innovative, and fun learning models, preparation of specially designed educational game media. A teacher must also do cognitive development before entering the class (Baharun et al., 2021). 
In this stage, the teacher prepares the activities for implementing role-playing games, arranged through RPPH, which is made to design the learning used at RA Uswatun Hasanah based on the existing curriculum.

RA Uswatun Hasanah conveyed some of the preparations made by the teacher before the teaching and learning process. in the form of Prota, Prosem, RPPM, and RPPH according to the Raudlatul Athfal level curriculum. Thus, the teacher already has a reference or guide to prepare for the learning process from yearly, semester, weekly, and daily. Teachers will not be confused about the themes and learning materials they will apply (Efandari, 2020).

The teacher prepares a scenario that will be displayed on role-playing. Second, the teacher provides a special class in implementing role-playing. Third, the teacher provides visual media that will be used in role-playing games. It will be easier for teachers to learn using a role-playing application model with some of these preparations.

Preliminary analysis and planning are needed before starting the lesson to make it easier for teachers to deliver lessons. Teaching preparation is one part of the teaching program that contains units of discussion to be presented in several meetings or face to face. Teaching preparation can be used as a basis for preparing lesson plans and, simultaneously, as a reference for teachers in carrying out learning activities so that they are more focused and run efficiently and effectively (Astuti et al., 2020). Learning planning is an activity of projecting what actions will be carried out in a lesson by arranging and responding to the learning components. The direction of the activity (objective), the side of the activity (material), how to deliver activities (methods and techniques), and how to measure it (evaluation ) becomes clear and systematic (Hilfi Hanifah, 2018).

Implementing the teaching and learning process for students is in several ways to prepare quality human resources and form a complete personality (Adisti, 2018). Therefore, in providing learning materials, some aspects must be developed and instilled in students, including cognitive, language, religious, moral, and social values. The education provided must touch on social aspects, including tolerance, caring, mutual respect, mutual respect, working together, empathy, and so on (Qasim \& Maskiah, 2016). With careful preparation and planning, teachers and students will find it easy to carry out the teaching and learning process, and the goals to be achieved can be directed that are easy to achieve.

\section{Application Role Playing Game}

At this stage, the teacher gives more confidence to students to play the role that has been determined. Introverted children at first still show an attitude of shame and lack of confidence. However, with the support of teachers and friends and role-playing models that are done repeatedly, their self-confidence will gradually appear.

Classical learning is applied in a special class that the teacher has prepared, namely the acting class. Role-playing engineering is carried out three times a week to overcome the learning mood of students. The role-playing application is carried out on Tuesdays, Wednesdays, and Saturdays. The rest of the models used are conventional models.

The steps were taken by the teacher when starting the role-playing application for students include: 


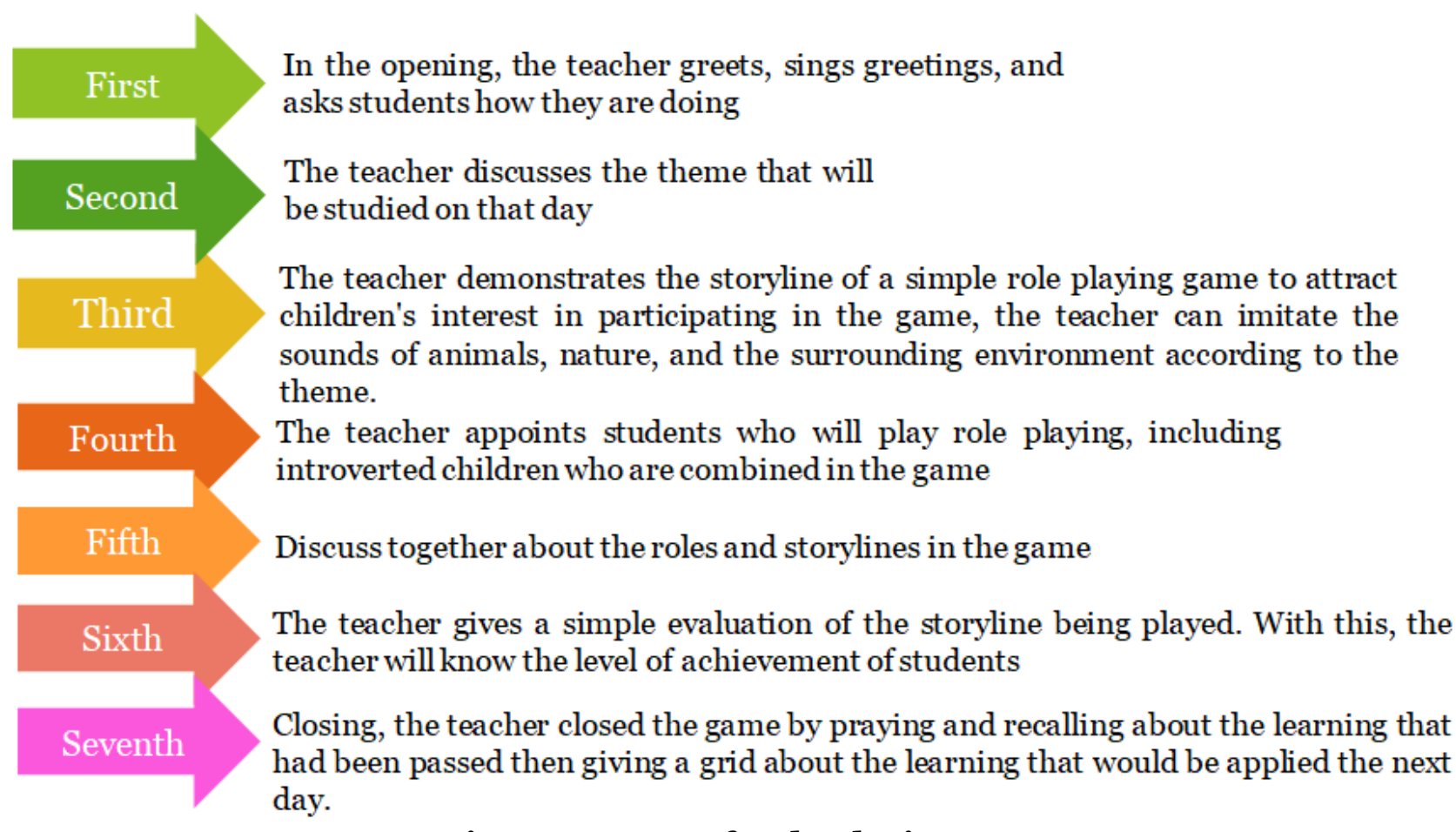

Figure 1. Steps of Role Playing Game

$\mathrm{RH}$, one of the teachers of RA Uswatun Hasanah, conveyed that the application of roleplaying carried out on his students was voluntary or not forcing. If one of the students was less interested in his role, the teacher did not force him to play it, but the teacher shifted it to a different role. Others by showing the role to be played are also interesting. Likewise, for introverted children at RA Uswatun Hasanah, the teacher provides stimulus and input so that children are interested in playing a role even though they have to choose friends (Himami, 2020).

Nevertheless, so far, in applying the role-playing model, RA Uswatun Hasanah's students are very interested and interested in playing the roles they get randomly assigned by the teacher. This model can provide a memorable and enjoyable experience so that it is difficult for students to forget. It is very interesting for students. It allows the class to be dynamic and full of enthusiasm, fosters enthusiasm for learning, and fosters a sense of togetherness through fun learning. Application is made as an example or simulation to understand the roles that exist in the characters to be played. Role-Playing Games are games where a player plays the role of a fictional character in an adventure narrative (Wildana et al., 2020). In making simulation characters, children are more interested and interested in carrying out activities according to the direction of the teacher. Role-playing engineering is used as a learning approach that is used to improve students' attitudes and knowledge. One of the learning models that can be integrated with dealing with introverted children is role-playing. The role-playing model is a learning model by doing or playing a character in a story (Rumilasari et al., 2016).

\section{Activity Documentation}

Documentation Stage Activities carried out at this stage are analyzing, synthesizing, interpreting, and explaining the information obtained. The data has been successfully obtained through data collection tools recorded by researchers. The observers confirmed, analyzed, and evaluated that. It can be seen whether the implementation of the application of the model has been following what was previously planned and obtains an increase of results according to the level of achievement of child development.

LS guardian of students said that their children, who had difficulty interacting, began to interact with their friends since the stimulation of role-playing games. This can be known after one of the teachers sent photos and videos (S, 2021). 


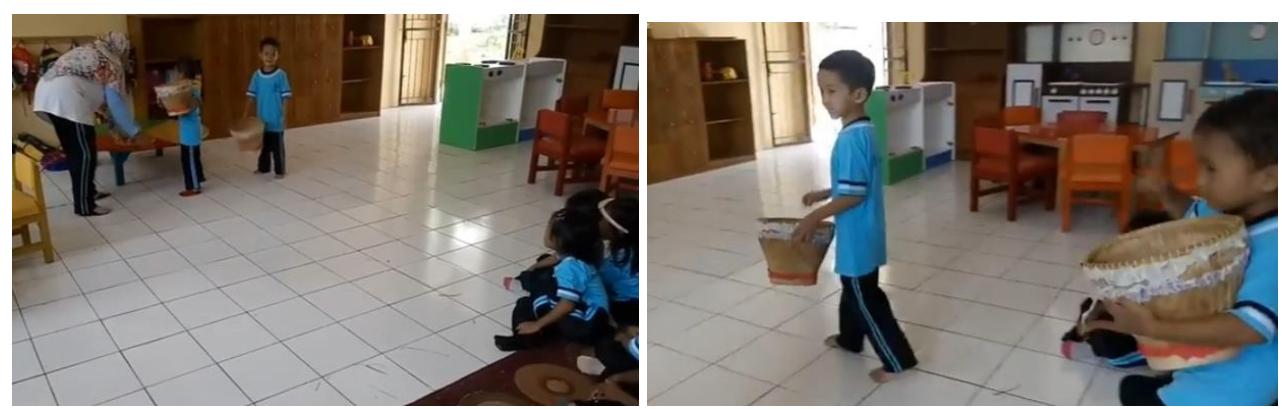

Figure 2. Role-Playing Game (Farmers' Role)

Based on the documentation obtained when using role-playing, it can be seen that an increase in introverted children's interactions with the environment is more communicative and mingling.

\section{Activity Evaluation}

Evaluation is a systematic and objective assessment of planned intervention, in progress or completed. Evaluation can also be interpreted as a series of activities comparing the realization of inputs, outputs, and results against plans and standards. Evaluation results are obtained during monitoring activities. The evaluation also assesses the results or products that have been produced from a series of programs. It is a basis for making decisions about the level of success that has been achieved and the next action needed.

According to the US, the head of RA Uswatu Hasanah, the things that are evaluated in the role-playing model activities in dealing with introverted children are; the development of introverted children before and after implementing role-playing, the level of communication between introverted children and normal children in general, the use of devices in games, and roleplaying game scenarios. The actual evaluation time can be done since the child enters during the learning process, and the results are given to the parents at the end of the semester (Hasanah, 2020).

This study focuses on the development of introverted children, where introverted children who have quiet behavior and do not like to play with other friends are given a stimulus to interact with their friends. Role-playing games conducted at RA Uswatun Hasanah show that introverted children's interest in role-playing games is higher than other games because with role-playing models, children are required to communicate with other people who play that role. These results were obtained in interviews, observations that the authors analyzed before stating that the development of introverted children in interacting increased slowly. The data collection model is following the facts in the field and what they are.

$\mathrm{RH}$ teacher of group A said the model of implementing role-playing games at RA Uswatun Hasanah could help teachers stimulate introverted children to be more interested in interacting with their friends. It can be seen from assessing children's achievements in anecdotal books made by teachers (Himami, 2020). FD as a teacher also emphasized that there are four introverted children in the institution who take part in learning with a role-playing game model that is stimulated more optimally by showing interaction when playing roles with friends even though sometimes they still choose friends when the game is implemented. However, this has significantly improved compared to before being given a role-playing model where children stay silent, do not talk much, and do not want to mingle with their friends. Of course, this will impact children's social-emotional development in the future (Firdausiah, 2020).

The following figure shows the developmental achievement of four introverted children using role-playing games at RA Uswatun Hasanah. 

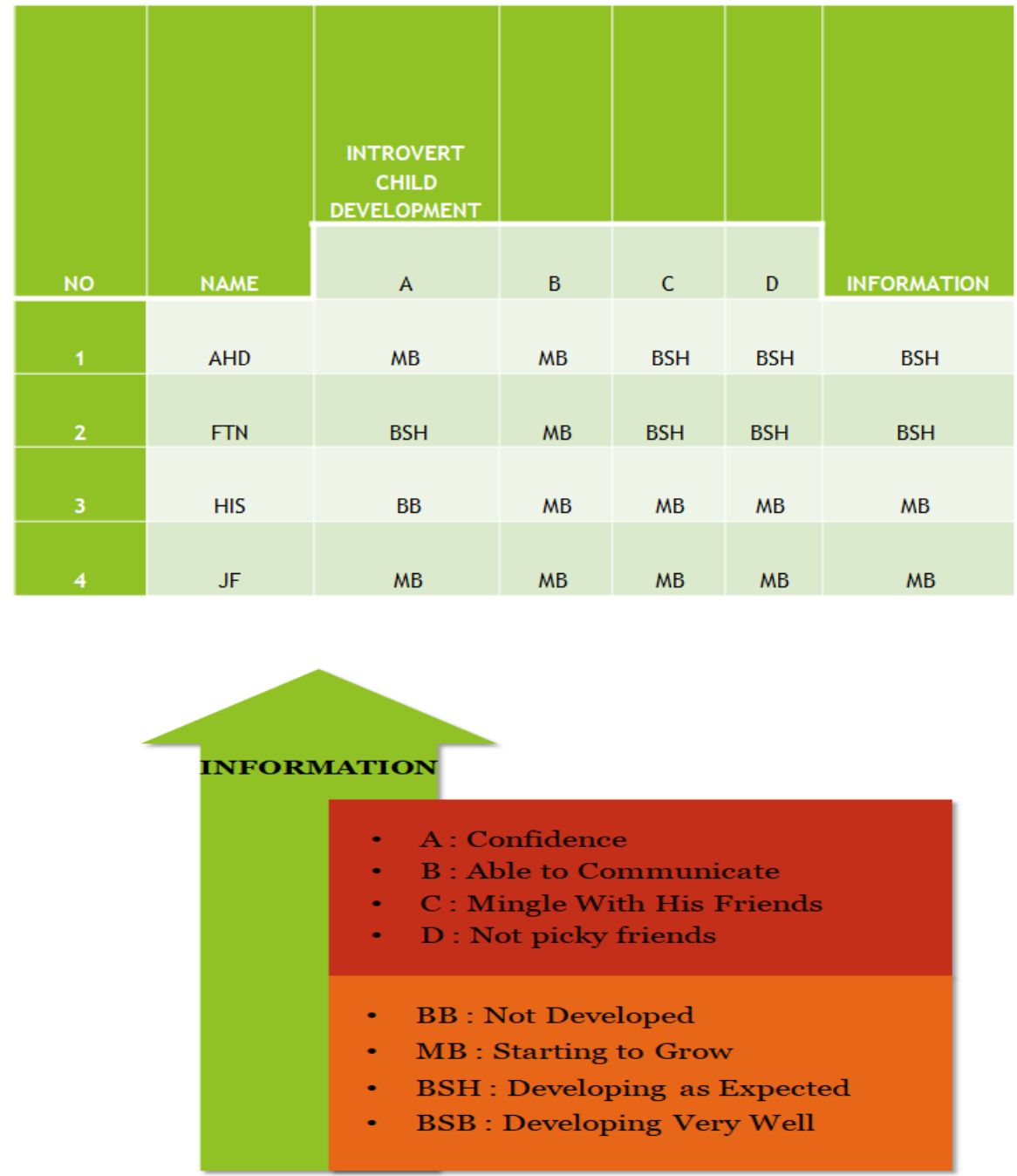

Figure 3. Development of Introvert Children

Evaluation often understood in education, is limited to assessment only (Fitrianti, 2018). This assessment is carried out in a formative and summative manner. When an evaluation has been carried out, it is considered to have conducted an evaluation. Such understanding is not very precise. The implementation of the assessment tends to only look at the achievement of learning objectives. In this case, in the educational process, it is not only the value that is seen but many factors that make a program successful or not. Assessment is only a small part of the evaluation. Evaluation should also be understood as part of supervision. Evaluation does not only deal with the value measured based on the completion of questions, but the evaluation of educational programs will examine many factors (Daud et al., 2020). Thus program evaluation needs to be introduced to all educators because evaluation is very important in developing the quality of education (Ashiong P. Munthe, 2015). Evaluation can encourage students to be more active in learning continuously, encourage teachers to improve the quality of the learning process further, and encourage schools to improve additional facilities and the quality of student learning $(B, 2017)$.

The purpose of the evaluation is to achieve the goals set and can be implemented. The evaluation results are intended for re-planning and serve as the final administration and management. 


\section{CONCLUSION}

The implications of role-playing, especially at RA Uswatun Hasanah, activate the introverted children in the learning process. They begin to be able to mingle and even adapt to their friends, albeit slowly. It takes patience, persistence, and the ability to innovate accompanied by the creativity of teachers to understand the character of their students so that the expected level of achievement can be targeted optimally. The use of role-playing at RA Uswatun Hasanah cannot be generalized to all educational institutions for children this age. This is based on the characteristics of learners and analysis of the internal and external environment at the institution. It provides an opportunity for further researchers to examine and research with different cases and characteristics and find new findings in improving research.

\section{REFERENCES}

Adisti, A. R. (2018). Internalization of Javanese Unggah-Ungguh ( Etiquette ) Character in Modern Era Through Personality Course At English Education Department. Al-Ishlah: Jurnal Pendidikan, 10(2), 216-230.

Ahour, T., \& Haradasht, P. N. (2014). The Comparative Effect of Using Competitive and Cooperative Learning on the Reading Comprehension of Introvert and Extrovert EFL Learners. Advances in Language and Literary Studiesnces, 5(4), 207-214.

Anggraini, W., \& Putri, A. D. (2019). Penerapan Metode Bermain Peran (Role Playing) dalam Mengembangkan Kognitif Anak Usia 5-6 Tahun. JECED: Journal of Early Childhood Education and Development, 1(2), 104-114.

Ashiong P. Munthe. (2015). Pentingya Evaluasi Program Di Institusi Pendidikan: Sebuah Pengantar, Pengertian, Tujuan dan Manfaat. Scholaria, 5(2), 1-14.

Astuti, D. P., Muslim, A., \& Bramasta, D. (2020). Analisis Persiapan Guru Dalam Pelaksanaan Pembelajaran Matematika Di Kelas Iv Sd Negeri Jambu 01. Jurnal Wahana Pendidikan, 7(2), 185-192.

Ayuningtiyas, V. (2013). Metode Bermain Peran (Role Playing) Dalam Upaya Menumbuhkembangkan Keterampilan Berbicara Bahasa Indonesia Pada Anak Usia Dini Di Tk Bhayangkari 17 CIMAHI. Jurnal EMPOWERMENT, 2(2), 48-55.

B, M. (2017). Evaluasi Belajar Peserta Didik (Siswa). Idaarah: Jurnal Manajemen Pendidikan, 1(2), 257-267.

Baharun, H. (2016). Pengembangan Media Pembelajaran Pai Berbasis Lingkungan Melalui Model. Cendekia, 14(2), 231-246.

Baharun, H., Zamroni, Amir, \& Saleha, L. (2021). Pengelolaan APE Berbahan Limbah untuk Meningkatkan Kecerdasan Kognitif Anak. Jurnal Pendidikan Anak Usia Dini, 5(2), 13821395.

Buckland, M. K., \& Lund, N. W. (2012). Boyd Rayward, Documentation, and Information Science Michael. Information Science, 62(2), 1-423.

Daud, A., Novitri, N., \& Hardian, M. (2020). Evaluation of the Teacher Professional Education Program (Ppg): English Students' Perspective. AL-ISHLAH: Jurnal Pendidikan, 12(2), 185200. https://doi.org/10.35445/alishlah.v12i2.286

Efandari, I. E. (2020). Interview.

Filina, Z. (2013). Efektifitas Metode Role Playing Untuk Meningkatkan Kosakata Kosakata Anak Tunarungu. E-JUPEKhu (Jurnal Ilmiah Pendidikan Khusus), 1(1), 311-318.

Firdausiah. (2020). Interview.

Fitrianti, L. (2018). Prinsip Kontinuitas dalam Evaluasi Proses Pembelajaran. Al-Ishlah: Jurnal Pendidikan, $10(1)$, 89-102. http://journal.staihubbulwathan.id/index.php/alishlah/article/view/68\%oAhttp://moraref.k emenag.go.id/documents/article/97874782241969537

Goh, S. L. (2016). Learning strategies and learner attitudes in the massively multiplayer online role-playing game cube world. 12(3), 203-216.

Hammer, J., Turkington, M., \& Designs, U. (2021). Designing Role-Playing Games That Address The Holocaust. 12(1), 42-53.

Hasanah, U. (2020). Interview.

Hilfi Hanifah, F. A. (2018). Manajemen Pembelajaran Bagi Anak Usia Dini Dalam Meningkatkan 
Kualitas Pembelajaran Di Pos Paud Dahlia 15. JURNAL COMM-EDU, 1(3), 24-29.

Himami, R. (2020). Interview.

Jacobs, G. (2014). Introverts Can Succeed with Cooperative Learning. Parole, 4(1), 83-93.

Kristin, F. (2018). meta-analisis pengaruh model pembelajaran role playing terhadap hasil belajar IPS. Refleksi Edukatika: Jurnal Ilmiah Kependidikan, 8(2). https://doi.org/10.24176/re.v8i2.2356

Kurniawan, T. (2019). Keefektifan Kelompok Psikoedukasi Teknik Role Play Dan Modeling Simbolik Untuk Meningkatkan Komunikasi Interpersonal Mahasiswa Universitas Veteran Semarang.

Lasaiba, D. (2016). Pola Pengembangan Model Pembelajaran Pendidikan Anak Usia Dini Di Lingkar Kampus Iain Ambon. Jurnal Fikratuna, 8(2), 79-104.

Martin, C. (2018). Role-Playing in Children's Literature: Zilpha Keatley Snyder and "The Egypt Game". American Journal of Play, 10(2), 208-228.

Nursyahrurahmah. (2017). Hubungan Antara Kepribadian Introvert Dan Kelekatan Teman Sebaya Dengan Kesepian Remaja Relationship Between Introvert Personality And Friendships Friendly By The Lonely Adolescent. Jurnal Ecopsy, 4(2), 113-116.

Qasim, M., \& Maskiah. (2016). Perencanaan Pengajaran Dalam Kegiatan Pembelajaan. Jurnal Diskursus Islam, O4(3), 484-492.

Rumilasari, N. P. D., Tegeh, I. M., \& Ujianti, P. R. (2016). Pengaruh Metode Bermain Peran (Role Playing) Terhadap Kemampuan Berbicara pada Anak Kelompok A. E-Journal Pendidikan Anak Usia Dini Universitas Pendidikan Ganesha, 4(2), 1-11.

S, L. (2021). Interview.

Saihu, M., \& Umar, N. (2021). The Humanization of Early Children Education. Al-Ishlah: Jurnal Pendidikan, 13(1), 173-185. https://doi.org/10.35445/alishlah.v13i1.419

Sakinah, A. (2018). Konseling Kelompok Emotional Intellegence Pada Tipe Kepribadian Introvert. Al-Tazkiah, 7(1), 1-24. https://doi.org/10.20414/altazkiah.v7i1.649

Selian, N. (2019). the Management of Pre-School Towards Accreditation Standards. AL-ISHLAH: Jurnal Pendidikan, 11(2), 197. https://doi.org/10.35445/alishlah.v11i2.150

Siska, Y. (2011). Penerapan metode bermain peran (role playing) dalam meningkatkan keterampilan sosial dan keterampilan berbicara anak usia dini. Jurnal Penelitian Pendidikan, Edisi Khusus, o2(08), 31-37.

Sudarsosno, B. (2017). Memahami Dokumentasi. Acarya Pustaka, 3(1), 47-65.

Wildana, M. N., Kasmui, \& Nuryanto. (2020). Keefektifan Desain Media Role Playing Games Berbasis Android Pada Materi Redoks Dan Tata Nama Senyawa. Jurnal Inovasi Pendidikan Kimia, 14(1), 2524-2535.

Windiastri, F., \& Nurhaeni, N. (2020). Hubungan Pola Asuh Ibu dan Perkembangan Sosial Emosional Anak Usia Prasekolah di Bogor. Jurnal Persatuan Perawat Nasional Indonesia (JPPNI), 4(2), 67. https://doi.org/10.32419/jppni.v4i2.180

Yunita, W. (2016). Improving Students' Speaking Skill By Using Stad (Student Teams Achievement Divisions). Al-Ishlah: Jurnal Pendidikan, 8(1), 136-153.

Zen, E. F., Muslihati, M., Hidayaturrahman, D., \& Multisari, W. (2020). Pelatihan Perilaku Respek, Empati dan Asertif Melalui Metode Role Play untuk Mencegah Bullying Di Sekolah Menengah Pertama. Abdimas Pedagogi: Jurnal Ilmiah Pengabdian Kepada Masyarakat, 3(1), 40-47. https://doi.org/10.17977/umo50v3i1p40-47 